\title{
Domenico Esposito \\ Decorative Principles Between the Public and Private Spheres in Pompeii: Contexts, Patrons and Artisans
}

\begin{abstract}
This paper attempts to analyse the relationship between decorated spaces and the choices made by both patrons and painters with respect to the production of that decoration. As a case study, we shall focus here on the Nilotic theme, which was ever-present in Pompeii during the period of the Fourth Style, in both public and private settings. A discussion of the meaning (or of various potential meanings) of these scenes, particularly in relation to a room's entire decorative programme, permits us to consider the manner in which certain spaces were perceived by ancient observers. The interactions between patrons and painters, as well as the socio-economic and cultural implications of these relationships, should always underlie any discussion focusing on ancient decorative contexts and their viewers.
\end{abstract}

\section{Introduction}

This paper analyses the relationship between decoration and architecture in the public and private contexts of Pompeii, with particular attention given to the relationship between decorated spaces and the manner in which they were perceived by ancient observers. In what follows, we shall focus specifically on the recurrence of Nilotic themes in certain spatial contexts. The choice to focus on this theme is not arbitrary, but derived from observing what is known (or what has been preserved) of the decoration of the city's main public buildings, along with what has been documented in private homes. The starting point, therefore, is the available evidence, as well as comparisons between the different types of buildings.

A useful fil rouge is the fact that much of this decoration was created by the same group of painters, members of the so-called 'Vettii Workshop'1, who decorated numerous public and private buildings in Pompeii between A.D. 62 and 79. This circumstance will permit us, at the conclusion of this paper, to offer some general considerations about the choices made by the painters in relation to the buildings they set out to decorate, as well as those made by the patrons who commissioned the work from them. In particular, we shall attempt to answer the following questions:

1) How did the design of a space itself act upon its viewers and users?

2) How might the 'action context' in which viewers were engaged affect the perception of decorative elements?

3) In what way did the intentions of patrons and artists influence the production of specific forms of decor?

\section{Themes and building types}

In the following pages, we shall analyse the decoration of a series of public and private buildings, exploring the potential for shared meanings across the corpus, as well as new interpretations that

1 On the Vettii Workshop, see in particular Esposito 2009, 49-132, with a list of building complexes decorated by them on $49 \mathrm{n}$. 372. On the existence of painters' workshops (or in any case stable professional connections that tied decorators together), the proceedings of the 'Mani di pittori' conference (Moormann 1995) represents a fundamental contribution. For Fourth Style painters' workshops, see the numerous publications by the present author, as well as a recent contribution by Francesca Bologna: Esposito 1999; 2007; 2009; 2011; 2016, 2017; Bologna 2019. 
Fig. 1: Stabian Baths, nymphaeum (F).

Fig. 2: Stabian Baths, nymphaeum (G), west wall: niche with mosaic.
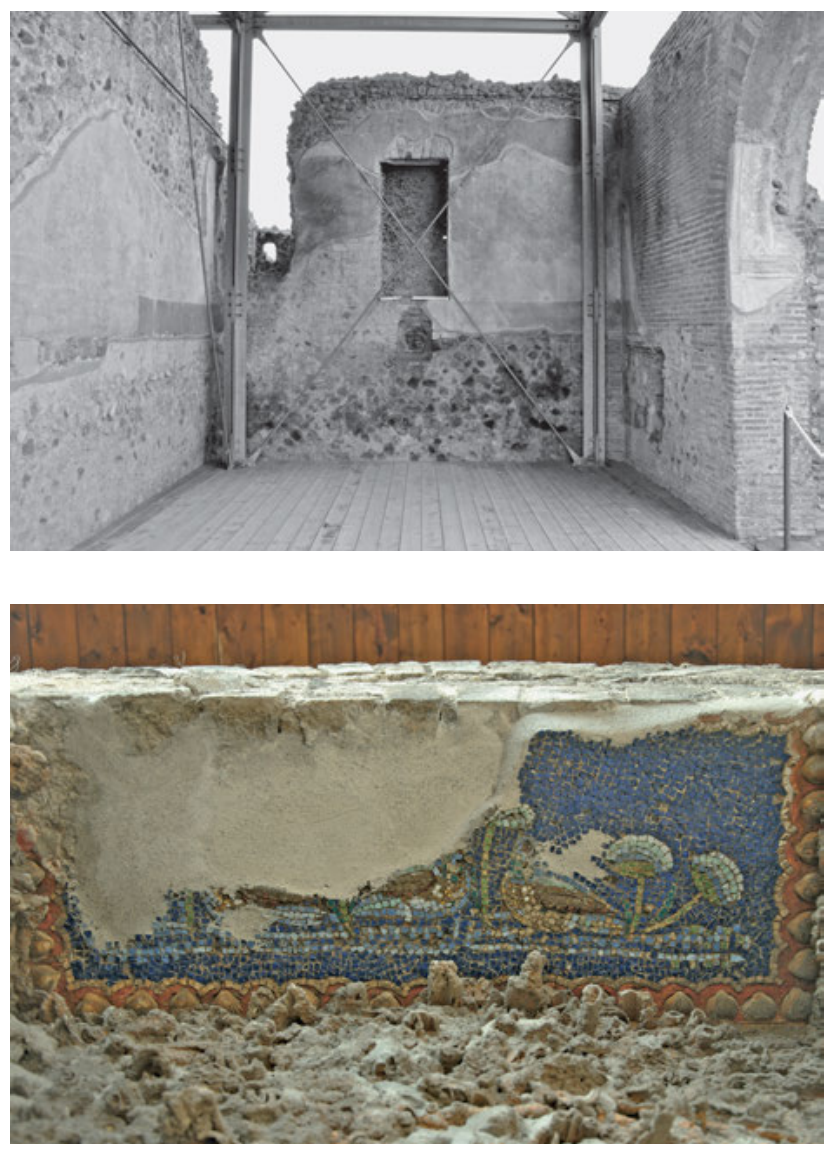

might be applied to the decoration based on the perceived function of spaces or the actual activities that took place within them. The Stabian Baths ${ }^{2}$ (VII 1,8) at Pompeii represent a central example in this discussion, because they exhibit a highly elaborate decorative programme that includes figurative themes comparable to those employed in other building complexes. The two large nymphaea $(\mathrm{F}, \mathrm{G})^{3}$ that flank the natatio (D) on the west side of the palaestra once presented very rich decoration ${ }^{4}$, which is today still visible to a limited degree due to its extremely poor state of conservation (Fig. 1). However, the decoration can be reconstructed thanks to numerous detailed drawings produced during the area's excavation and the so-called 'Plastico di Pompei', a $19^{\text {th }}$ century cork model of the city preserved in the Museo Archeologico Nazionale di Napoli ${ }^{5}$. A predella was positioned above a high marble dado and decorated by Nilotic landscapes populated with pygmies alternated with yellow panels showing sea monsters between pairs of dolphins. The middle zone presented garden views on a blue background with fountain statues resembling sphinxes. The landscapes were framed by red bands with plant motifs on which statues of satyrs and nymphs holding up fountain basins were painted ${ }^{6}$. The Nilotic surroundings displayed on this predella were also referenced in the mosaic panels showing marshlands with ducks that decorated the ceilings of the fountain niches on the back wall of the two rooms (Fig. 2) ${ }^{7}$. The decoration of the nymphaea

2 On the wall and floor decoration of the Stabian Baths, see De Vos - De Vos 1979, 81-95; PPM VI (1996) 149-219 s.v. VII 1, 8, Terme Stabiane (V. Sampaolo) 149-150.

3 The rooms discussed throughout this paper are described by the numbering and lettering systems employed in Pompeii: Pitture e Mosaici.

4 PPM VI (1996) 149-219 s. v. VII 1, 8, Terme Stabiane (V. Sampaolo) 175 Fig. 20.

5 See Lauritsen, this volume, 127 n. 23.

6 PPM Disegnatori (1995) 572-776 s. v. N. La Volpe (I. Bragantini - V. Sampaolo) 658-659 Figs. 103-104. 662 Fig. 108. 7 PPM VI (1996) 149-219 s.v. VII 1, 8, Terme Stabiane (V. Sampaolo) 176 Figs. 46-47. 


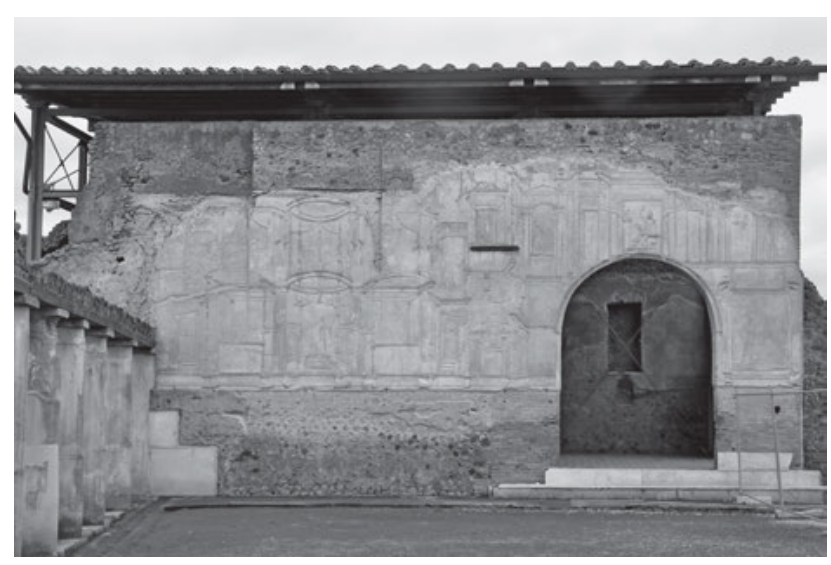

Fig. 3: Stabian Baths, palaestra (C), stucco decoration on the west wall.

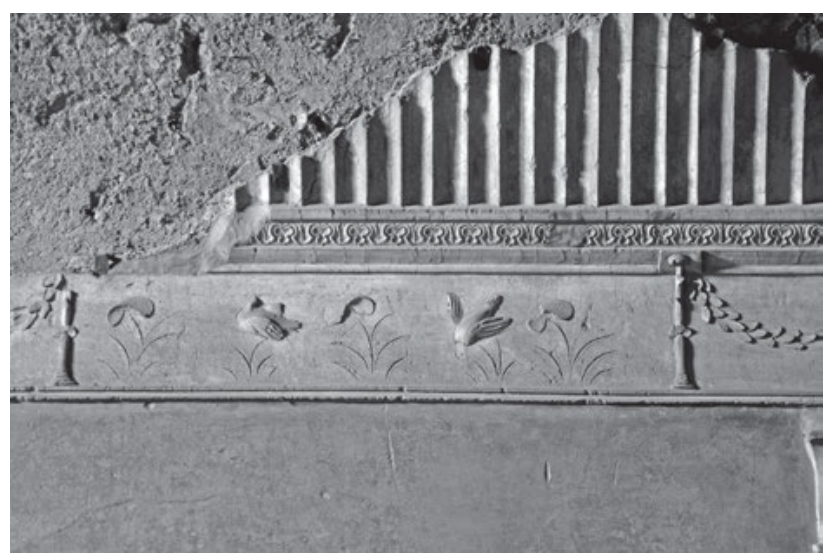

Fig. 4: Stabian Baths, women's caldarium (IX), north wall: detail of the stuccoed frieze presenting ducks in a marshy landscape.

was mirrored on the wall that faced towards the palaestra by a lively architectonic-illusionistic composition in polychrome stucco and paint (Fig. 3$)^{8}$, in which water-related themes also made an appearance, including two panels depicting the myth of Hylas9. The decorative programme presented by the palaestra (C) and its annexes (nymphaea $\mathrm{F}$ and $\mathrm{G}$ ) found parallels in the decoration of the adjacent bathing areas. The motif of the Nilotic landscapes, for example, is suggested also in the white stucco frieze that decorates the upper part of the walls of the female caldarium (IX) ${ }^{10}$, a design that displays ducks and other birds sitting on marsh plants (Fig. 4).

Many of the themes presented by the decoration of the Stabian Baths also appear in the Sarno Baths (VIII 2,17) and the Suburban Baths (VII, Ins. Occ. 16), both of which were partly decorated by the Vettii Workshop ${ }^{11}$. In the Sarno Baths, a blue frieze with Nilotic landscapes populated by pygmies (Fig. 5) runs around the border of the pool in the frigidarium (7). On one of the room's walls, which is decorated with a scheme that strongly recalls that found in the Temple of Isis (VIII 7,28), a panel with a purification scene performed by a fluvial deity appears ${ }^{12}$. On one of the polychrome

8 PPM Disegnatori (1995) 238-431 s. v. G. Abbate (I. Bragantini) 419 Fig. 246.

9 PPM VI (1996) 149-219 s.v. VII 1, 8, Terme Stabiane (V. Sampaolo) 169-170 Figs. 36-37; PPM Disegnatori (1995) 572-776 s. v. N. La Volpe (I. Bragantini - V. Sampaolo) 663 Fig. 109.

10 PPM VI (1996) 149-219 s. v. VII 1, 8, Terme Stabiane (V. Sampaolo) 212-213 Figs. 115-117.

11 On the attribution of the decoration of the frigidarium (7) in the Sarno Baths to the Vettii Workshop, see Salvadori 2018. Even today, the decoration of the Suburban Baths remains almost completely unpublished. Nevertheless, the decoration of the frigidarium (9) and the stuccoed ceiling of the apodyterium (6) can be attributed to the same painters that worked at the Stabian Baths.

12 See PPM VIII (1998) 94-135 s.v. VIII 2, 17-21, Complesso a sei piani delle Terme del Sarno (V. Sampaolo) 110 Fig. 25. 
Fig. 5: Sarno Baths, frigidarium (7), frieze with pygmies.

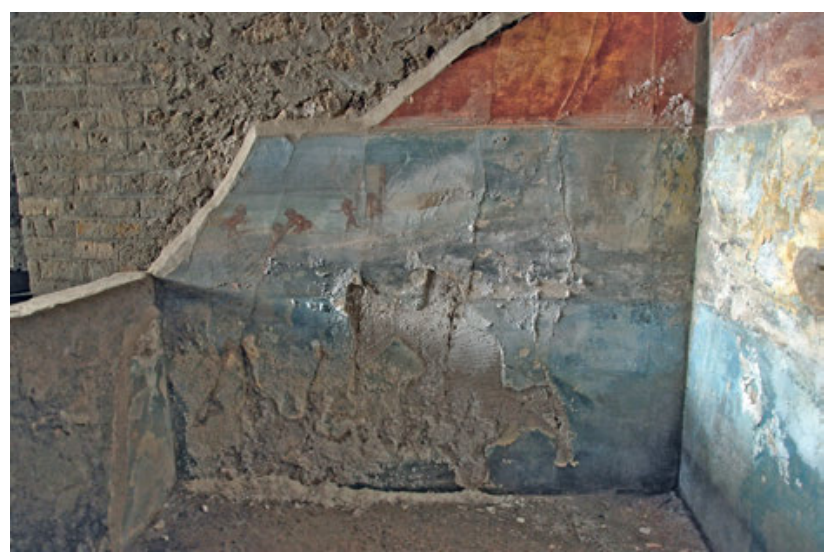

Fig. 6: Sarno Baths, frigidarium (7), decoration of lunette.

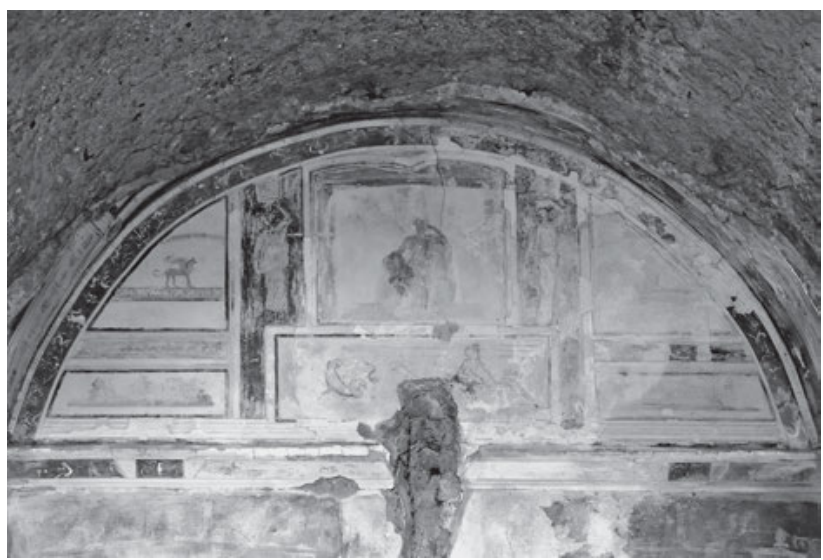

stucco panels that decorate the ceiling, meanwhile, the theme of Hylas appears once more, just as it did in palaestra (C) of the Stabian Baths ${ }^{13}$. Finally, a lunette on the north wall was painted with a panel that portrays a fluvial deity sitting on a rock, holding an amphora from which water gushes forth (Fig. 6) ${ }^{14}$.

The frigidarium (9) of the Suburban Baths presents a compendium that includes the decorative repertoire employed in the Stabian Baths. The room is dominated by a polychrome mosaic nymphaeum with a central panel depicting Mars in flight, his weapons taken from him by a crowd of cupids (Fig. 7). The frieze above it shows a maritime thiasus and views of shrines built along the coast. The walls of the pool itself are decorated by large panels in which various figures and scenes appear: seascapes with fish and figures of Nereids riding bulls and sea horses, Nilotic landscapes with pygmies and scenes of naval battles (Fig. 8).

Thus, the users of the public baths of Pompeii could admire visual themes associated directly with the world of the palaestra, such as depictions of heroes and gods, or objects and attributes alluding to sporting victories. In other spaces they found themselves immersed in an exotic world characterised by Nilotic landscapes, as well as depictions of seascapes, hunting scenes and naumachiae. It seems significant that in all of the examples mentioned so far, the Nilotic imagery almost always had a direct connection to water, either actually present, as in the pools of the frigidaria or

13 See PPM VIII (1998) 94-135 s. v. VIII 2, 17-21, Complesso a sei piani delle Terme del Sarno (V. Sampaolo) 111 Figs. $27-28$.

14 See PPM VIII (1998) 94-135 s. v. VIII 2, 17-21, Complesso a sei piani delle Terme del Sarno (V. Sampaolo) 107 Fig. 19. 108 Fig. 20. 109 Fig. 22. 

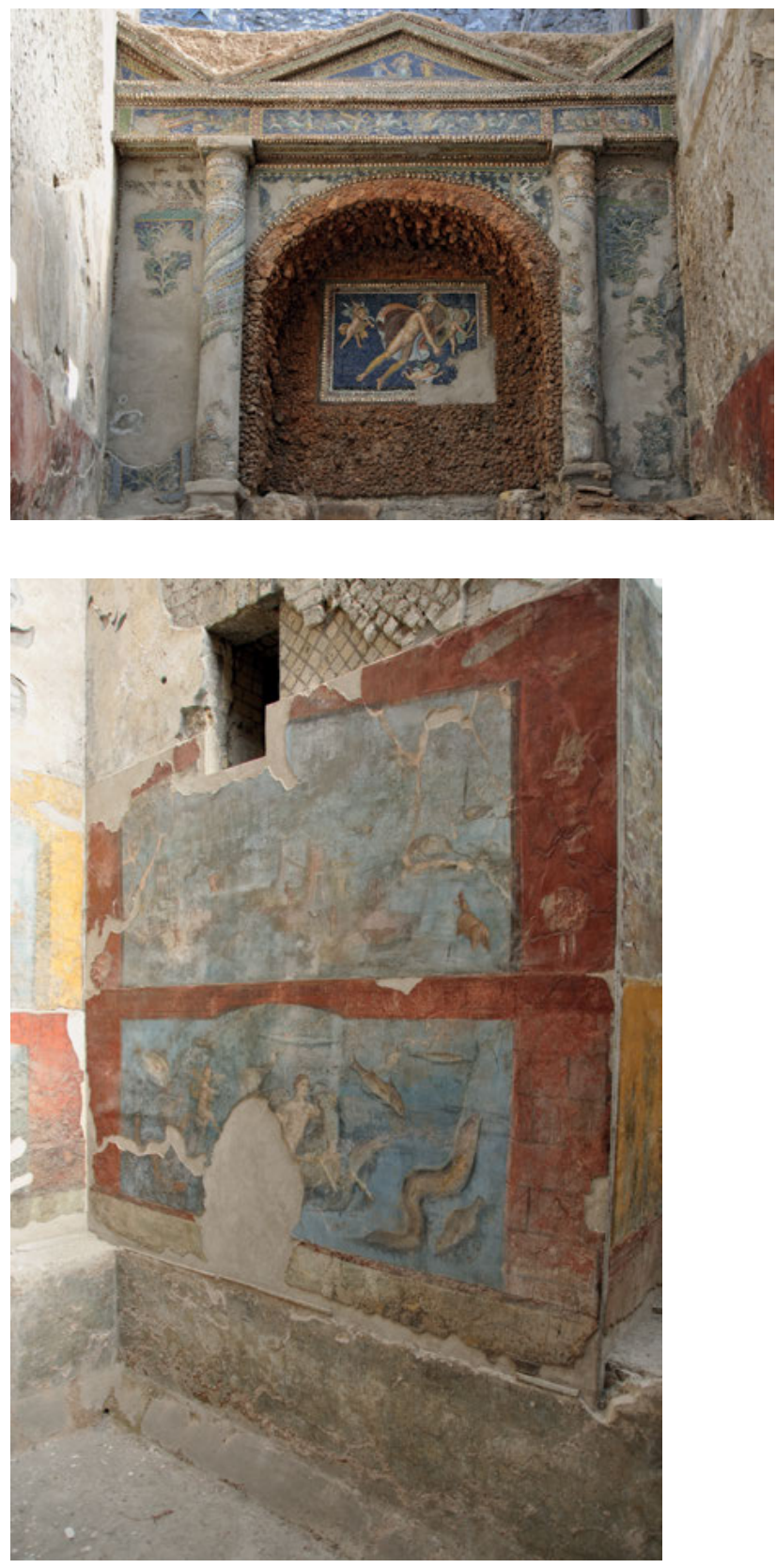

the fountains of the nymphaea, or merely evoked, through the imagery of marshlands, seascapes or gardens populated by fountains.

If we extend the scope of our analysis to private buildings, it becomes evident that the same themes can be found there, too, in spaces that have functions analogous to those of the public buildings, such as private balnea, and in spaces that have a different function entirely, such as porticos, gardens, oeci and triclinia. A particularly pertinent example appears in the frigidarium (44) of the Casa del Centenario (IX 8,3.7). Here, the swimming pool is surrounded by Nilotic landscapes with pygmies, inserted into wide red frames that contain images of gardens ${ }^{15}$. The choice to place
Fig. 7: Suburban Baths, frigidarium (9), mosaic fountain.
Fig. 8: Suburban Baths, frigidarium (9), detail of the pool's east wall. 
Fig. 9: Casa del Centenario nymphaeum (33).

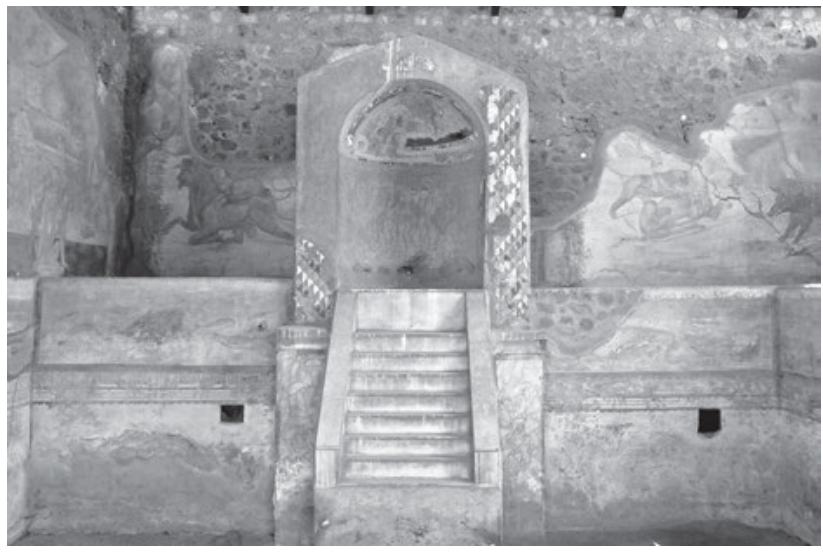

the scenes with pygmies around the pool is an interesting one. It resembles precisely what we see in the frigidaria of the Sarno and Suburban Baths (Figs. 5 and 8). Here, partially-immersed bathers could examine the pygmy frieze at eye level, while the figures themselves shimmered upon the surface of the water.

There is another area in the Casa del Centenario that displays the same decorative themes as its counterpart in the Stabian Baths: the nymphaeum (33) (Fig. 9). This room is paved in cocciopesto and contains a pool positioned in front of a fountain-nymphaeum decorated in mosaic and furnished with a cascade made of marble-covered steps. Below the steps is a panel - today almost completely unrecognisable - depicting a river god, the iconography of which mirrors that of the fluvial deity in the frigidarium of the Sarno Baths. The pool is surrounded by a crypta ${ }^{16}$, which is decorated with a painted dado depicting garden shrubbery and climbing plants amongst which exotic birds appear ${ }^{17}$. A continuous frieze running above the dado shows maritime landscapes populated by fish and ducks ${ }^{18}$ as well as marshlands with additional waterfowl ${ }^{19}$. The walls that enclose a terrace above the niche are occupied by two types of images: large hunting scenes with wild animals and garden scenes depicting statues that resemble sphinxes ${ }^{20}$. A comparison between the paintings found in nymphaeum (33) and frigidarium (44) in the Casa del Centenario and the decoration employed in the Suburban Baths shows how areas with analogous functions can present similar decorative themes and systems, whether in ostensibly public or private buildings. This fact leads us to hypothesise that the users of these spaces likely perceived them in a similar way, despite the different social context.

As noted above, however, these decorative themes were also adopted for spaces with entirely different functions, especially in private settings. One example of this phenomenon is the fauxgrotto triclinium (83) in the Praedia of Julia Felix (II 4,3). Facing onto a large garden with a large euripus (8), the back wall of the triclinium (83) contains a stepped cascade from which water flowed directly onto the pavement, between the couches of the marble-clad triclinium

16 PPM IX (1999) 903-1104 s. v. IX 8, 3.7, Casa del Centenario (V. Sampaolo) 1001 Fig. 185. 1007 Fig. 199. 1023 Fig. 233. 1024 Fig. 235.

17 PPM IX (1999) 903-1104 s. v. IX 8, 3.7, Casa del Centenario (V. Sampaolo) 996 Fig. 176. 999 Fig. 180. 1007-1008 Figs. 199-201. 1013 Fig. 211.

18 PPM IX (1999) 903-1104 s. v. IX 8, 3.7, Casa del Centenario (V. Sampaolo) 1007-1010 Figs. 199-205. 1013-1014 Figs. 211-214.

19 PPM IX (1999) 903-1104 s.v. IX 8, 3.7, Casa del Centenario (V. Sampaolo) 1001 Fig. 184. 1002-1004 Figs. $186-192$. 1017 Fig. 219. 1018-1019 Figs. 222-226.

20 PPM IX (1999) 903-1104 s.v. IX 8, 3.7, Casa del Centenario (V. Sampaolo) 1000-1001 Figs. 182-185. 1004-1005 Figs. 193-194. 1010 Fig. 206. 1015-1017 Figs. 216-219. 1020 Fig. 228. 


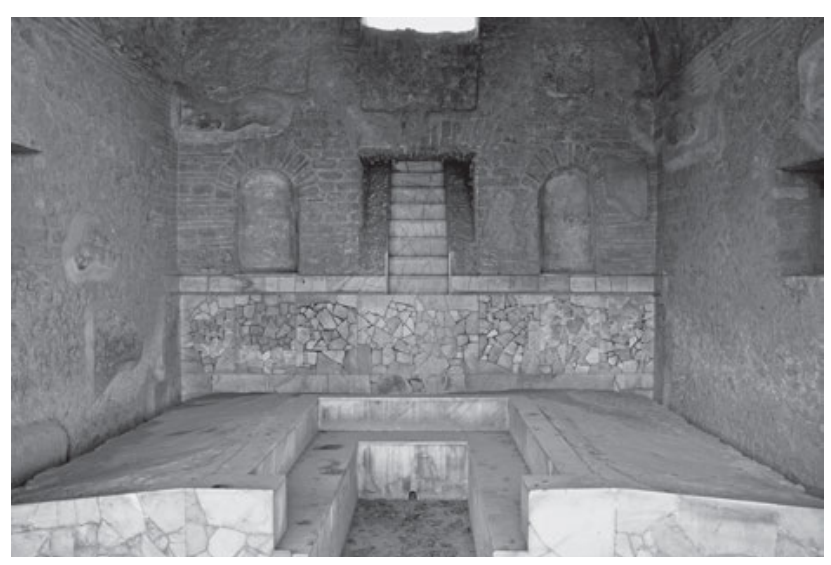

Fig. 10: Praedia of Julia Felix, triclinium (83).

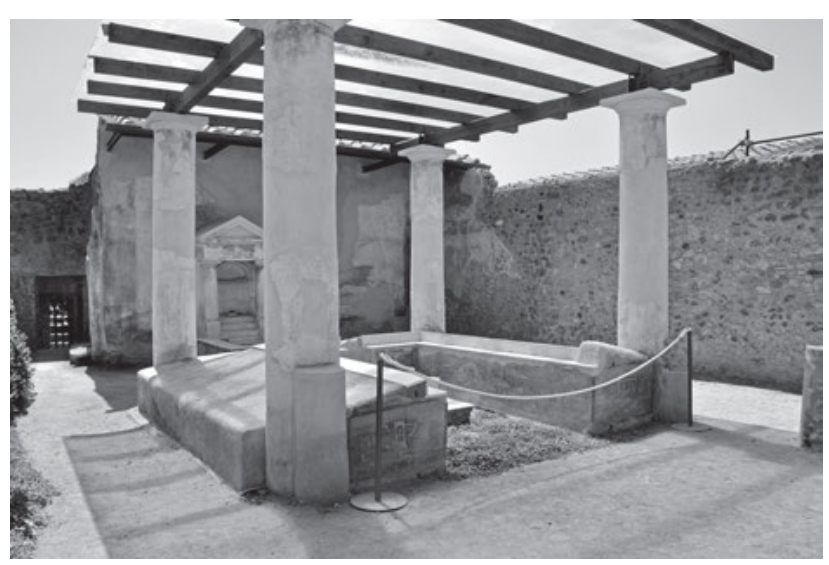

Fig. 11: Casa dell'Efebo, garden (23), view of the triclinium.

(Fig. 10). The walls were decorated with a megalographic depiction of a Nilotic landscape populated by pygmies ${ }^{21}$, while the barrel-vaulted ceiling of the hall was covered in travertine incrustations, so as to suggest the surroundings of a natural grotto from which a spring flowed forth.

An analogous arrangement can be observed in the garden (23) of the Casa dell'Efebo (I 7,11) ${ }^{22}$. Here, between the couches of a masonry triclinium decorated with a Nilotic frieze depicting dwarfs and pygmies, runs a canal fed by a fountain that sprang forth from an aedicula positioned above (Fig. 11). Yet another example appears in a small cubiculum (1) in the Casa dei Pigmei (IX 5,9), which is decorated by a large-scale frieze - almost a megalography, like that found in the triclinium of the Praedia of Julia Felix - that originally extended across all four walls (Fig. 12) ${ }^{23}$. The frieze displays Nilotic landscapes occupied by pygmies engaging in a variety of activities: they fight with crocodiles and hippopotami, fish in the river, transport wine amphorae on ships, make votive offerings at sanctuaries and so on ${ }^{24}$. Furthermore, occupants of this cubiculum could catch glimpses of the garden (i) through a window located in the south wall, while the north and west walls were originally decorated with scenes of animals hunting one another within a river landscape. ${ }^{25}$

21 See PPM III (1991) 184-310 s. v. II 4, 3, Villa di Giulia Felice (V. Sampaolo) 263-267 Figs. 135-141.

22 Barrett 2019, with previous bibliography.

23 At present, only the tectorium can be seen on the west wall, but it is possible to identify traces of red paint that indicate the presence of a dado and a terminal cornice, which demonstrates that this wall too was originally decorated with the same scenes.

24 PPM IX (1999) 486-527 s. v. IX 5, 9, Casa dei Pigmei (I. Bragantini) 506-519 Figs. 36-61.

25 The hunting scene can still be seen in a reproduction of the house in the Plastico di Pompei. 
Fig. 12: Casa dei Pigmei, cubiculum (l), megalography with dwarfs.

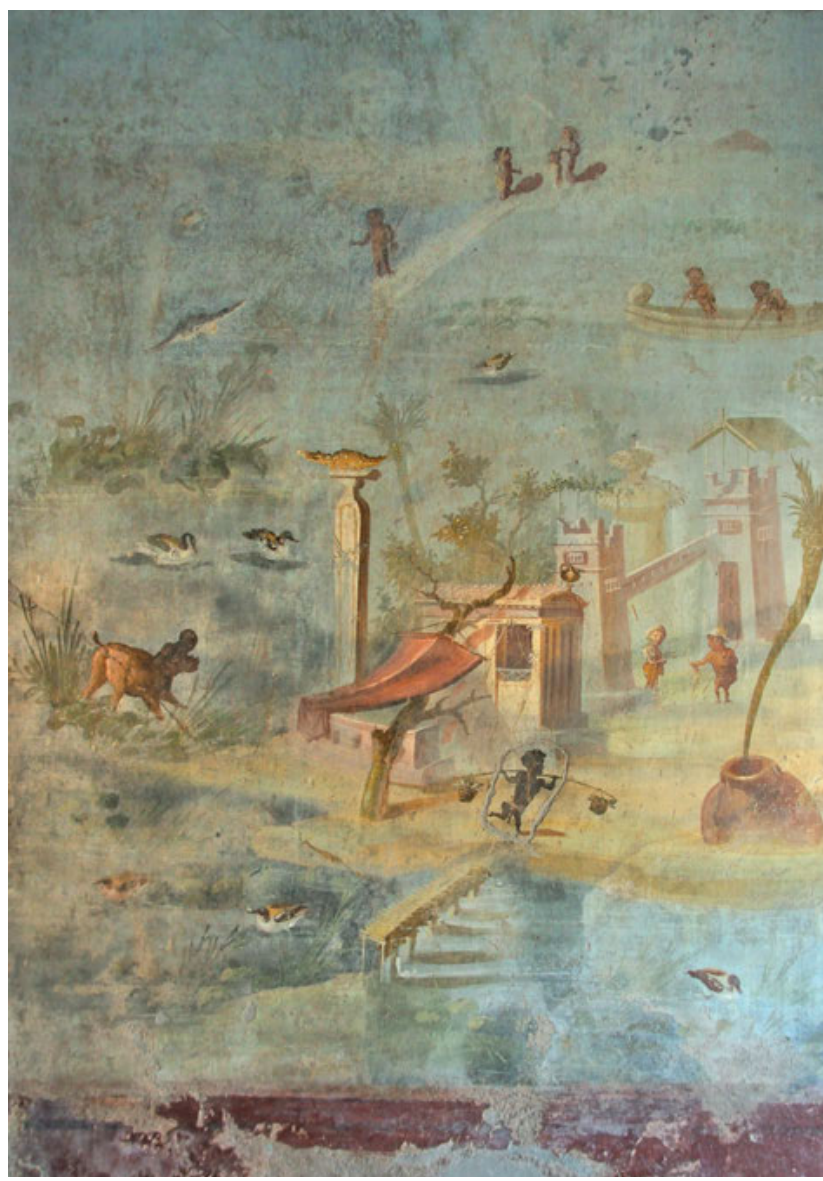

More difficult to interpret is the recurrence of this Nilotic theme in other types of public buildings, such as temples. Pinakes with pygmies appear, for example, in the decorative programmes of portico (A) in the Sanctuary of Apollo (VII 7,32) ${ }^{26}$ and portico (1) in the Temple of Isis ${ }^{27}$ (Figs. 13 and 16). The original position of the scenes in the Sanctuary of Apollo is uncertain, because the paintings were not adequately documented and have almost completely disappeared ${ }^{28}$. From the brief descriptions that are available ${ }^{29}$ and from the watercolour paintings by Francesco Morelli ${ }^{30}$ and William Gell ${ }^{31}$ produced a couple of years after the building's excavation, it can be deduced that the scenes were placed inside predelle located below panels containing mythological paintings that decorated the middle zone of the wall ${ }^{32}$. The pictorial fields of this middle zone were also framed by

26 PPM VII (1997) 286-304 s. v. VII 7, 32, Tempio di Apollo (V. Sampaolo) 296 Fig. 15.

27 PPM VIII (1998) 732-849 s.v. VIII 7, 28, Tempio di Iside (V. Sampaolo) 741 Fig. 10. 743 Fig. 14. 744 Fig. 16. 746 Fig. 19. 756 Fig. 37. 764 Fig. 50. 771 Fig. 61. 773 Fig. 64. 774 Fig. 66. 778 Fig. 73. On the decoration of the Temple of Isis, see Sampaolo 1992; 1994; 1995; Moormann 2007.

28 The paintings in the Sanctuary of Apollo are now almost completely lost, but detailed watercolours were produced by François Mazois, Félix-Emmanuel Callet and Pasquale Maria Veneri shortly after the discovery of the building. Excellent reproductions are found in Heslin 2015, 42f. Figs. 6-7 and passim. On the decoration of the Sanctuary of Apollo, see Moormann 2011, 71-82, in particular 82. For another interpretation of the sanctuary's decoration, with which the current author does not always agree, see Heslin 2015, 27-193.

29 Summaries can be found in Moormann 2011, 81 f. and Fig. 28 and Heslin 2015, 119-122 Figs. 57-58.

30 Museo Archeologico Nazionale di Napoli, ADS 697.

31 Gell 1819, Folio 61a-b. 62. 64a-b.

32 Morelli's drawings depict two long friezes that are almost complete, while Gell reproduces only some details: see Gell 1819, Folio 61a-b. 62. 64a-b. 


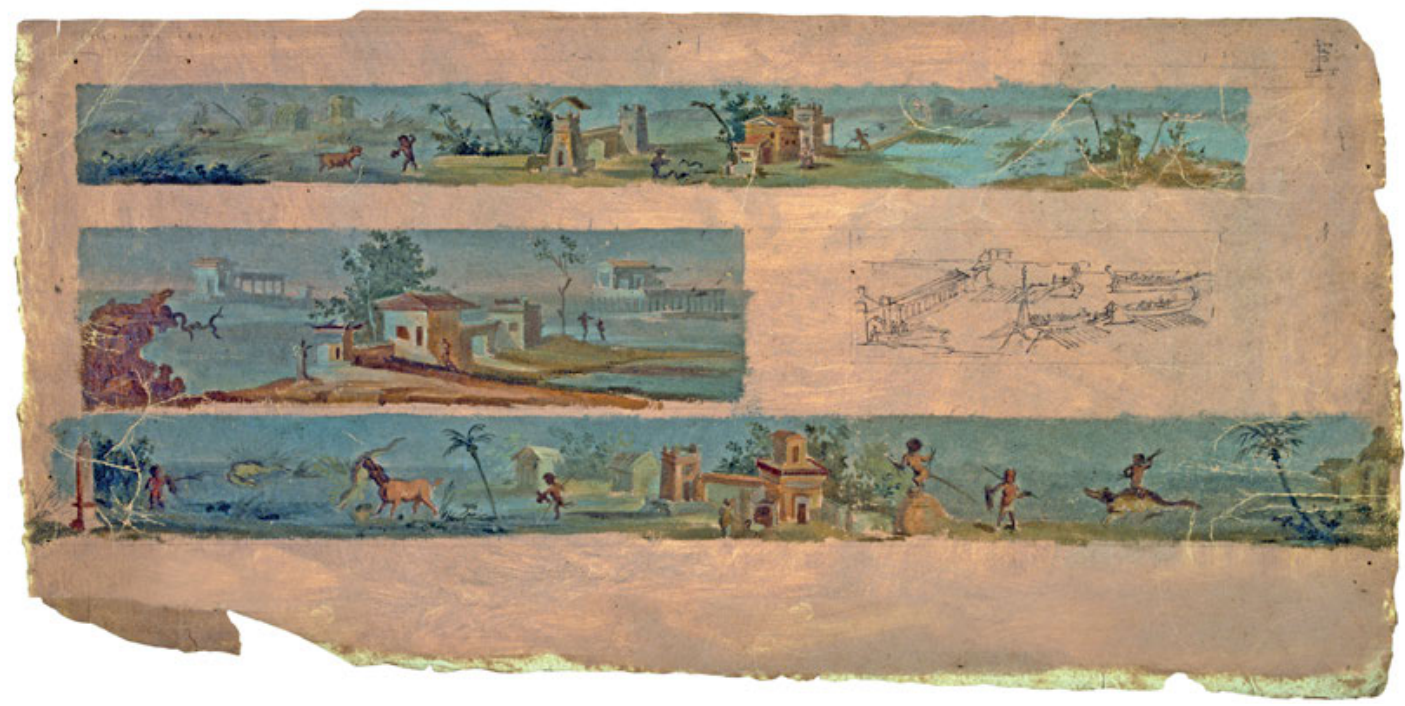

Fig. 13: Watercolour by F. Morelli depicting the predella with dwarfs in the Sanctuary of Apollo.

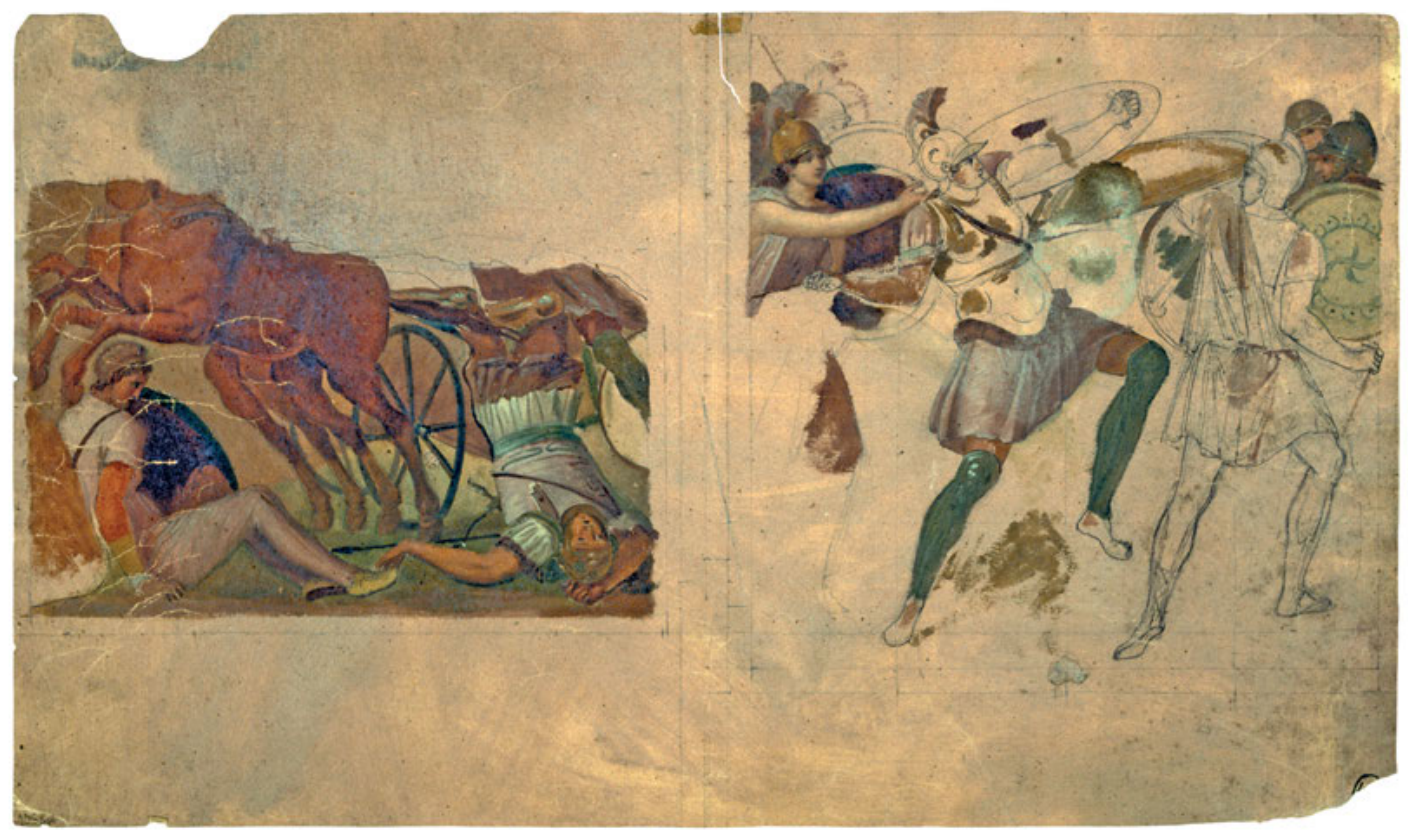

Fig. 14: Watercolor by F. Morelli recording panels from the Sanctuary of Apollo that depict scenes from the Iliad.

architectural vistas, the lower sections of which were themselves decorated by predelle depicting landscapes with small rustic shrines, villas and naval battles ${ }^{33}$ (Fig. 13).

The mythological panels depicted episodes from the Iliad ${ }^{34}$, a subject undoubtedly appropriate for the decoration of a temple (Fig. 14). Vitruvius also points out how the troianae pugnae were a perfect subject for the decoration of porticos and ambulationes ${ }^{35}$. Walking along the porticos in the Sanctuary of Apollo, visitors' attention must have been drawn first by these mythological scenes. The painted architectural framework that enclosed them helped create the illusion that they were

33 Gell 1819, Folio 60. 63a-b. 67. 71. 91.

34 In 1818, Morelli reproduced some of the tableaus in watercolour; they also appeared in lithographs made by Anton von Steinbüchel (1833). Among those that are identifiable: battle scenes, the struggle between Achilles and Agamemnon, as well as Achilles dragging the body of Hector and Priam with Achilles. See Moormann 2011, 76-77; Heslin 2015, 51-138.

35 Vitr. De arch. 7, 5, 2-3. 


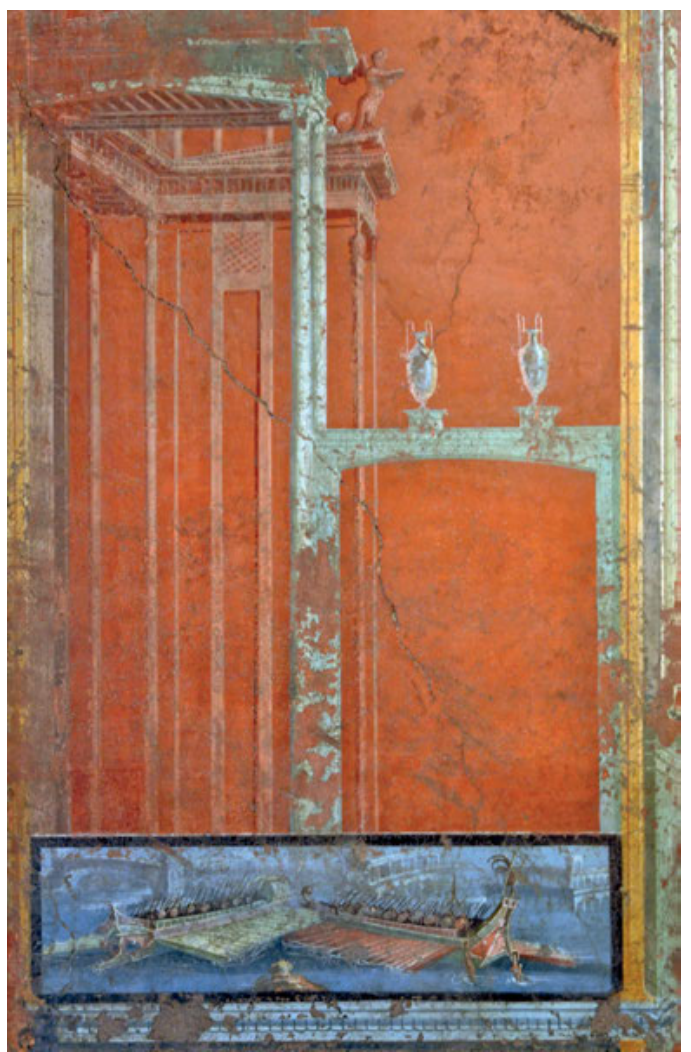

Fig. 15: Temple of Isis, portico (1), detail of the wall decoration.

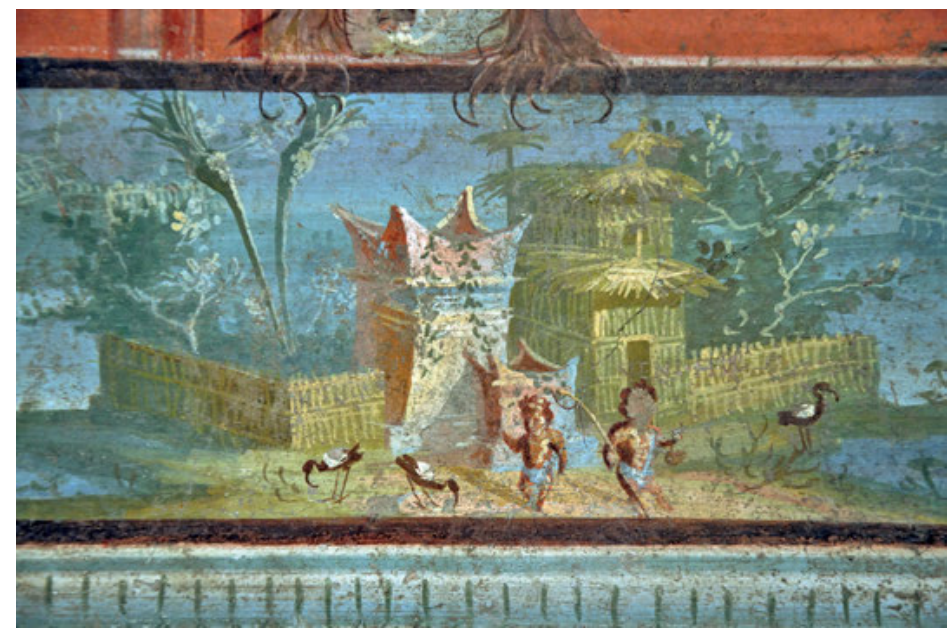

Fig. 16: Temple of Isis, portico (1), panel with dwarfs.

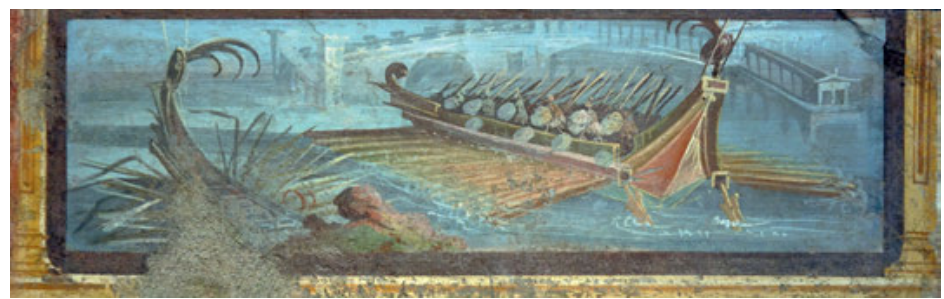

Fig. 17: Temple of Isis, portico (1): panel with naumachiae.

tabulae pictae hung upon the wall ${ }^{36}$. An emphasis on the figure of Achilles, a recurring protagonist in many of the scenes (Fig. 14), has led to hypotheses about a connection to a revival of this hero par excellence and the renewal of the Augustan aurea aetas during the reign of $\mathrm{Nero}^{37}$. If the choice of scenes from the Iliad for the decoration of the portico can be considered fully compliant with the political ideology of the time, the adoption of Nilotic themes for the predelle is perhaps less coherent with its broader pictorial programme. According to Eric Moormann, the Nilotic scenes, alongside the depictions of landscapes and naumachiae, belong to the standard repertoire of the Fourth Style, and it is therefore difficult to assign a specific meaning to them that is coherent with the decorative context as a whole ${ }^{38}$. Peter Heslin, on the other hand, follows an interesting hypothesis first formulated by Carlo Bonucci in the $19^{\text {th }}$ century, according to which the Nilotic scenes containing pygmies could have functioned as a comic counterpart to the Trojan saga shown in the main panels ${ }^{39}$. Bonucci's astute interpretation permits, in fact, a better contextualisation of the Nilotic theme, which at first glance seems inappropriate for the decoration of a sanctuary: by depicting dwarfs and pygmies, the erudite subject matter presented in the mythological tableaus is subverted in a comedic vein.

\footnotetext{
36 Heslin erroneously hypothesises that some panels were actually created elsewhere and subsequently inserted into the wall. See Heslin 2015, 173-178.

37 On the importance and meaning of the Iliadic scenes, see Schefold 1975, reiterated by Moormann 2011, $78 \mathrm{f}$. On the imitatio Achillis in the Neronian era see Bragantini 2009, 196-200.

38 Moormann 2011, $81 \mathrm{f}$.

39 Heslin 2015, 121 f.; Bonucci 1827, 153: 'Nelle altre (pitture) si vede ricordata qualche scena delle battaglie de' Pigmei contro le Grù. Comico contrapposto, col quale il Pittore ha voluto forse tradurci in diverso linguaggio l'ironia con cui Omero solea contemplare le gagliardie de' topi e de’ ranocchi’.
} 
A similar procedure was employed for the decoration of the plutei in garden $(\mathrm{g})$ of the Casa del Medico (VIII 5,28), on which a parody of the Judgment of Solomon appears, with the historical figures involved transformed into dwarfs. The effect is enhanced by the coupling of this episode with scenes of pygmies battling exotic animals and engaging in orgiastic banquets ${ }^{40}$. The predelle of the Sanctuary of Apollo demonstrate, therefore, how it is not always easy to reduce the complexity of a decorative programme and arrive at a correct interpretation of all its elements, including those that appear to be not coherent with the overall context.

The Temple of Isis presents a different situation. The organisation of the sanctuary seems to have been conceived above all to encourage the viewer to explore visually the full extent of the space. At the entrance to the temple complex, one's gaze is immediately drawn to the purgatorium, as well as the mass of the temple itself, built at the centre of the small courtyard. Gradually, visitors might have recognised the altars, inscriptions and statues erected along the aisles of the portico.

The paratactic decorative scheme in portico (1) was applied without adapting it to the architectural space that enclosed $\mathrm{it}^{41}$. The walls do not display mythological panels, but rather vignettes containing figures of Isiac priests ${ }^{42}$ alternating with Egyptianising landscapes. All of them are small in size. The only pictorial element on which the attention of viewers could linger was a panel depicting Harpocrates, inserted into a large niche positioned on the back wall of the east portico, and preceded by a monumental prothyron aligned with the façade of the temple. Behind the temple, five arches gave access to the ekklesiasterion, a space decorated with large-scale sacred landscapes and mythological panels. These are the only mythological scenes discovered in the temple's vicinity, apart from those located in the priests' private cubiculum. A sacrarium located at the south end of the complex was decorated in a style entirely different to the portico and ekklesiaterion; it has been suggested that this is the work of one of the cult's followers ${ }^{43}$.

Thus, the decoration of the Temple of Isis seems to have been rigidly and hierarchically organised to direct the gaze towards the principal elements of the cult. The secondary decoration on the walls of the portico displays the same subjects present in the Sanctuary of Apollo: depictions of temples and shrines, naumachiae and Nilotic scenes with pygmies, as well as still lifes (Figs. 15-17). All of these represent forms of exotic imagery that we might generally characterise as 'Egyptianising'. In the landscapes, for example, Egyptian altars, obelisks and shrines often appear. The Nilotic scenes do not adopt a humorous tone as in the Sanctuary of Apollo and Casa del Medico, but rather display genre scenes similar to those in room (1) of the Casa dei Pigmei. The naumachiae- one of which includes not only ships in battle order, but in the midst of a genuine combat (Fig. 17) - may refer to actual battles, perhaps even Actium ${ }^{44}$. Finally, the still lifes, which represent one of the most pervasive elements of Fourth Style painting, may refer to the prosperity guaranteed by Isis ${ }^{45}$.

40 Clarke 2007, 98-105 Pls. 4-8.

41 The decoration scheme does not take into account, for example, the large niche that occupies part of the portico's south wall.

42 On representations of Isiac priests, see Moormann 2018.

43 See Moormann 2011, 156 f. 162.

44 On possible connections between the naumachiae and actual battles, see Avilia - Jacobelli 1989, 146-148; Moormann 2011, 159-161.

45 Moormann 2011, 159-161. 


\section{Spatial design and perception, patrons and artisans}

After this long overview, we can now return to the questions posed at the beginning of this paper, starting with the first one: how could the design of a space itself have an influence on its viewers or users? The preceding pages have laid out how Nilotic imagery was one of the most sought-after themes for the decoration of both public and private spaces during the period of the Fourth Style, and resulted in a proliferation of depictions of fluvial landscapes populated by pygmies and dwarfs. These images, often analysed in isolation ${ }^{46}$, take on different meanings depending upon the spaces that they decorate, as well as their connection to other themes and decorative motifs within them ${ }^{47}$. Initially, the depictions of pygmies appear to relate directly to the function of the environment in which they are used, particularly in settings that are characterised by the real or suggested presence of water: in the frigidaria and nymphaea of the Stabian, Suburban and Sarno Baths, the balneum and nymphaeum of the Casa del Centenario, as well as the triclinia of the Praedia of Julia Felix and the Casa dell'Efebo and the garden of the Casa del Medico. In all of these contexts, water seems to have played a central role with respect to the perception of the imagery. Visitors to the baths, in particular, were literally immersed in a phantasmagorical and playful world, characterised by the presence of pygmies engaged in humorous (or outright obscene) activities just above the water level.

John Clarke is convinced that the small courtyard of the Casa del Medico, which was paved in cocciopesto, was perhaps kept continuously half-flooded so that the scenes depicting dwarfs and pygmies reflected upon the water's surface, and in a certain way appeared to be alive ${ }^{48}$. The same effect was achieved in the two nymphaea in the Stabian Baths, the nymphaeum in the Casa del Centenario and the small euripus that bisects the Casa dell'Efebo's summer triclinium. The effect must have been even more evocative in the triclinium in the Praedia of Julia Felix, where the diners, stretched out on their klinai, were surrounded by megalographic Nilotic landscapes, imagery that dramatically expanded the closed space of the dining hall. The entrance to triclinium (83), which faced onto the large garden with its pool-euripus, contributed to the effect, merging the Nilotic scenes evoked on the painted walls with the actual landscape of the garden. Cubiculum (1) in the Casa dei Pigmei must have achieved a similar effect. Despite the small size of the room, the Nilotic megalography extended the space beyond the boundary of the walls, and the large window facing onto the garden allowed viewers to contemplate the vista of a fluvial landscape.

As we have seen, in all of these examples there appears to be a direct connection between the choice of the decorative theme - Nilotic landscapes with dwarfs and pygmies - and water. This connection could be employed for the arrangement of different types of environments: nymphaea and rooms in bath suites, but also viridaria, triclinia, oeci and cubicula diurna inside the domus. The design of these spaces seems to have been conceived for the amusement and entertainment of the customers of the baths or for visitors to the domus. These decorated spaces stimulated different levels of attention. When entering the palaestra of the Stabian Baths, or the gardens of the Praedia of Julia Felix or Casa dell'Efebo, visitors were surrounded by a multiform decorative apparatus, in which the architecture, foliage of the garden, fountains, euripi and nymphaea with their accompanying array of sculptures, as well as the rich and varied pictorial decoration, were intended to impress the viewer immediately. During the visit to a bath house, or over the course of a convivium, viewers had the opportunity to let their gaze linger, fixing their attention on the various visual stimuli that surrounded them.

In other cases, the depictions of pygmies helped shape the semantic connotations of an environment in connection with other themes. This allows us also to address the second question posed at the beginning of this paper: how might the activities in which viewers were engaged affect their

46 See Versluys 2002; Tybout 2003; Bricault et al. 2007.

47 See Barrett 2017; 2019.

48 Clarke 2007, 101 f. Pls. 4-5. 
perception of decorative elements? The best examples for analysing this aspect are the Nilotic friezes that decorated the Temple of Isis and Sanctuary of Apollo in Pompeii. In the Temple of Isis, the Nilotic theme played a secondary role in the overall programme employed in the sanctuary's porticos. The decorative scheme adopts a paratactic structure with large fields in red divided by slender architectural views that incorporate pinakes depicting various types of scenes: still lifes ${ }^{49}$, naumachia $e^{50}$, landscapes with Egyptianising shrines ${ }^{51}$ and images of pygmies ${ }^{52}$. The pygmies also appear on the long spiral frieze set above the middle zone of the portico's wall ${ }^{53}$. Eric Moormann has argued that the pinakes allude to the prosperity of the Roman Empire, which was placed under the protection of the goddess worshipped in the sanctuary and guaranteed by the military victories of Rome, perhaps evoked in the pinakes depicting naumachia ${ }^{54}$. Therefore, the paintings with pygmies in the Temple of Isis contribute, together with all the other elements of the building's decorative programme, to evoke a vaguely Egyptianising atmosphere within a hybrid complex, in which Egyptian and Roman elements exist alongside one another ${ }^{55}$.

In the Sanctuary of Apollo, on the other hand, the predelle with depictions of pygmies constitute a comedic variatio of the Iliadic paintings placed in the centre of the middle zone. They therefore enrich the decorative context in which they appear with additional meaning. Visitors to the temple would have encountered numerous stimuli depending on whether they focused their attention on the mythological panels, characterised by the epic theme, or on the predelle, which presented, albeit indirectly, a parody of the same themes. In adopting this double register (cultured/ serious for the main panels, comedic/satirical for the lower zone), the painters of the Vettii Workshop were taking part in a well-established figurative and literary tradition that dated back to the Late Republican period. The frieze from triclinium (C) of the Villa della Farnesina in Rome and the frieze depicting the 'feast of the dwarfs' found in the triclinium of the so-called Domus dei Bucrani underneath the Scuola di Traiano at Ostia ${ }^{56}$ offer exceptional testimony of this custom. As JeanMarc Moret has astutely demonstrated, such images can be connected to the dwarfs associated with Mark Antony and consequently to the conflict between Antony and Octavian (also fought through imagery) that culminated in the former's defeat at Actium $^{57}$. Echoes of this practice, which recasts historical facts, religious rites or episodes derived from epic literature and mythology in a satirical or distorted manner, can also be found in Late Republican Pompeii. The Iliadic frieze from the Casa del Criptoportico (I 6,4) $)^{58}$, for example, sits in contrast to the depiction of the Olympic gods and heroes such as Theseus as dwarfs in atriolum (46) of the Casa del Menandro's bath suite (I 10,4) ${ }^{59}$.

However, the friezes with dwarfs and pygmies from the Late Republic represent an educated choice that remained the prerogative of high-status private clientele, who, in participating in the era's chief conflict, were adopting a political (or at least an ideological) stance that was potentially dangerous ${ }^{60}$. By including similar imagery in the Sanctuary of Apollo, the Vettii Workshop transposed this decorative choice into the public sphere, which in itself represents an interesting innovation. An explanation for this development can be found in the more relaxed political atmosphere

49 There are at least three still lifes preserved on the walls of the east and west porticos.

50 At least five naval battles can be counted, placed along all four sides of the portico.

51 These appear at least four times.

52 These can be seen only twice, both in the east portico.

53 See PPM VIII (1998) 732-849 s. v. VIII 7, 28, Tempio di Iside (V. Sampaolo) 756f. Figs. 36-39. 785 Fig. 85.

54 Moormann (2011, $160 \mathrm{f}$.) discusses the various interpretations of the temple's decorative programme.

55 Moormann 2011, 162.

56 Villa della Farnesina: Bragantini - Pirelli 2007; Mols - Moormann 2008, 37-44. Domus dei Bucrani: Bocherens 2012; Moret 2012a.

57 Moret 2012b.

58 Spinazzola 1953, 905-970.

59 Clarke 2007, 133-143. On the attribution of the friezes in the Casa del Criptoportico and Casa del Menandro to a single group of painters, see Esposito 2020.

60 Moret 2012b. 
of the second half of the $1^{\text {st }}$ century A.D., at least two generations after the battle at Actium, when the empire was well-established and prosperous; circumstances, in short, that made it possible to include the types of iconographic elements that in the past would have (at the very least) caused a certain degree of awkwardness.

The decorative choices made over time with regard to figurative themes, and the potential hierarchical relationship between these themes and decorated spaces as a whole, urge us to consider the third and most elusive question: in what way did the intentions of patrons and artists influence the production of specific forms of decor? As noted above, many of the buildings considered in this paper were decorated by a specific group of painters known as the Vettii Workshop. ${ }^{61}$ This is an important point of reference, because it offers the possibility to evaluate the production of a specific group of craftsmen in relation to the type (public/private) and the status (high/low) of the client.

The painters of the Vettii Workshop were able to propose a fairly large repertoire of images and decorative elements, which they could adapt to various spaces. In this sense it can be said that the decorators of the Vettii Workshop profoundly influenced the 'decorative landscape' of Pompeii during the Neronian-Flavian period. Visitors to the Stabian Baths, Macellum (VII 9,7), Sanctuary of Apollo and Temple of Isis were surely capable of recognising the decoration they encountered there. This is evidenced by the fact that the owners of some of the richest Pompeian domūs requested decoration clearly inspired by those of the public buildings decorated by the Vettii Workshop.

As we have seen, the Vettii Workshop was able to modulate its own decorative repertoire according to the building it was commissioned to paint. The Nilotic theme, with its depictions of fluvial landscapes populated by pygmies or dwarfs, was adapted each time to a specific setting and function. Thus, the friezes with pygmies in the nymphaea of the Stabian Baths and the frigidaria of the Sarno and Suburban Baths underline the atmosphere of escapism inherent to these places of relaxation and physical wellness. Water played a fundamental role in these surroundings, as was also the case in the triclinia of the Casa dell'Efebo and the Praedia of Julia Felix, as well as the garden of the Casa del Medico.

In sacred contexts, on the other hand, the painters of the Vettii Workshop used the Nilotic theme to evoke a different atmosphere, as in the Temple of Isis, where they sought to recreate or suggest an 'Egyptian', or at least vaguely 'Egyptianising', milieu. In the Sanctuary of Apollo, the Nilotic panels accompany the main theme developed in the Iliadic friezes of the portico, playing on the ironic reversal of the epic itself through the humorous struggles of the pygmies with hippopotami and crocodiles.

The great versatility of the Vettii Workshop's repertoire is not, however, sufficient to explain the specific choices made in the various types of spaces that required decoration. These choices must in all likelihood be attributed to the will of the clients, and thus the reasons for them are often difficult to specify, not least because these individuals often remain rather shadowy figures. Even if we take the Temple of Isis as an example, a place for which we have precise epigraphic data (constituted by the dedicatory inscription that recalls the temple's reconstruction by the Popidii), questions about the identity and the choices of the patrons remain open. Who chose the type of decoration for the walls of the portico? Was it Numerius Popidius Ampliatus, who, together with his son Celsinus and his wife Corelia Celsa, financed the reconstruction and decoration of the building? Was it the Isiac priests who indicated the themes appropriate for the redecoration of the sanctuary? Or was it perhaps the result of an agreement between the Popidii and the priests? To these questions there are obviously no straightforward answers. We can only respond with speculation. Emblematic is the example of the painted figures in the sacrarium ${ }^{62}$, which are judged to be of poor 'artistic quality' and therefore viewed as the work of an amateur, perhaps a local follower of the cult of Isis who frequented the sanctuary. What has not been considered, however, is that these paintings were

61 See Esposito 2009.

62 See PPM VIII (1998) 732-849 s. v. VIII 7, 28, Tempio di Iside (V. Sampaolo) 813--21 Figs. 170-176. 178-179. $182-183$. 
executed by artisans specialised in painting lararia and façades ${ }^{63}$. The manner in which the agathodaimones and the ship of Isis were rendered should be enough to dispel any doubts. Whoever commissioned the work in the Temple of Isis, then, turned to a workshop quite popular in this period for the decoration of the most important and representative spaces, while entrusting in the execution of the paintings in the so-called sacrarium to individuals specialising in façade and lararium paintings.

In many of the contexts analysed above, therefore, the role of the painters seems to be limited to satisfying the desires of the patrons and adapting their own rich decorative repertoire from one instance to the next. In conclusion, it can be said that the decorators were allowed a certain degree of freedom, especially with regard to the architectural frame and the secondary decorative motifs. The choice of the elements that carried semantic significance within the decorated space nevertheless remained up to the patrons. It was the patrons, in fact, who requested in each individual instance that the schemes be adapted to the function of the spaces requiring decoration, according to their own requirements, the message (cultic, cultural, ideological or political) they wished to communicate and their own taste. One can therefore agree with Annette Haug when she asserts that the notion of 'appropriateness' must have been constantly renegotiated between patrons and paint$\mathrm{ers}^{64}$. This relationship nevertheless seems to tilt in favour of the former, the patrons, who dictated the guidelines, even if only in the form of their desiderata. The latter, the decorators, were charged with the task of following these choices by relying on their own technical skills and the richness of the decorative repertoire that they were able to offer.

Domenico Esposito

Deutsches Archäologisches Institut - Zentrale Berlin

Podbielskiallee 69-71

14195 Berlin - Germany

archeomimmo@hotmail.com

\section{Illustration Credits}

Fig. 1-12. 15-17: D. Esposito, with authorisation of Ministero per i Beni Culturali e per il Turismo.

Fig. 13-14: L. Pedicini.

\section{Bibliography}

Avilia - Jacobelli 1989: F. Avilia - L. Jacobelli, Le naumachie nelle pitture pompeiane, RStPomp 3, 1989, 131-154

Barrett 2017: C. E. Barrett, Recontextualizing Nilotic Scenes. Interactive Landscapes in the Garden of the Casa dell'Efebo, Pompeii, AJA 121.2, 2017, 293-332

Barrett 2019: C. E. Barrett, Domesticating Empire. Egyptian Landscapes in Pompeian Gardens (Oxford 2019)

Bocherens 2012: C. Bocherens (ed.), Nani in festa. Iconografia, religione e politica a Ostia durante il secondo triumvirato (Bari 2012)

Bologna 2019: F. Bologna, Water and Stone: The Economics of Wall-Painting in Pompeii (A.D. 62-79), JRA 32, 2019, 97-128

Bonucci 1827: C. Bonucci, Pompei descritta (Naples 1827)

Bragantini 2009: I. Bragantini, La pittura di età neroniana, in: M. A. Tomei - R. Rea (eds.), Nerone, Catalogo della mostra Roma 12 aprile - 18 settembre 2011 (Rome 2011) 190-201

Bragantini - Pirelli 2007: I. Bragantini - R. Pirelli, Osservazioni sul fregio della Villa Romana della Farnesina, Annali di archeologia e storia antica 13/14, 2007, 221-231

63 On this type of painting, see Fröhlich 1991.

64 Haug, this volume. 
Bricault et al. 2007: L. Bricault - M. J. Versluys - G. P. Meyboom (eds.), Nile into Tiber. Egypt in the Roman World, Proceedings of the $3^{\text {rd }}$ International Conference of Isis Studies, Faculty of Archaeology, Leiden University, May 11-14, 2005 (Leiden 2007)

Clarke 2007: J. R. Clarke, Looking at Laughter. Humour, Power and Transgression in Roman Visual Culture 100 B.C. A.D. 250 (Los Angeles 2007)

De Vos - De Vos 1979: M. de Vos - A. de Vos, Die Wanddekorationen der Stabianer Thermen, in: H. Eschebach, Die Stabianer Thermen in Pompeji, DAA 13 (Berlin 1979) 81-95

Esposito 1999: D. Esposito, La 'Bottega dei Vettii’ a Pompei: vecchi dati e nuove acquisizioni, RStPomp 10, 1999, 23-61

Esposito 2007: D. Esposito, I pittori dell'officina dei Vettii a Pompei. Meccanismi di produzione della pittura parietale romana, BABesch 82, 2007, 149-174

Esposito 2009: D. Esposito, Le officine pittoriche di IV Stile a Pompei. Dinamiche produttive ed economico-sociali, Studi della Soprintendenza Archeologica di Pompei 28 (Rome 2009)

Esposito 2011: D. Esposito, Il sistema economico e produttivo della pittura romana. Esempi dall'area vesuviana, in: N. Monteix - N. Tran (eds.), Les savoirs professionnels des gens de métier. Études sur le monde du travail dans les sociétés urbaines de l'empire romain, Collection du Centre Jean Bérard 37 (Naples 2011) 65-85

Esposito 2016: D. Esposito, Il lavoro degli anonimi. Lo status quaestionis delle ricerche sull'operato dei pittori romani, BABesch 91, 2016, 173-195

Esposito 2017: D. Esposito, The Economics of Pompeian Painting, in: M. Flohr - A. Wilson (eds.), The Economy of Pompeii (Oxford 2017) 263-289

Esposito 2020: D. Esposito, La decorazione delle grandi residenze tardo-repubblicane in area Vesuviana, in: C. Capaldi (ed.), Augusto e la Campania. Da Ottaviano a Divo Augusto 14-2014 d.C., Atti del Convegno Internazionale Napoli 14-15 maggio 2015 (Naples 2020) 441-456

Fröhlich 1991: T. Fröhlich, Lararien und Fassadenbilder in den Vesuvstädten. Untersuchungen zur, 'volkstümlichen' pompejanischen Malerei (Mainz 1991)

Gell 1819: W. Gell, Dessins publiés dans l'ouvrage de Sir William Gell et John P. Gandy, Pompeiana: The Topography, Edifices and Ornaments of Pompeii, 1817-1819 (London 1819)

Heslin 2015: P. Heslin, The Museum of Augustus. The Temple of Apollo in Pompeii, the Portico of Philippus in Rome, and Latin Poetry (Los Angeles 2015)

Mols - Moormann 2008: S. T. A. M. Mols - E. M. Moormann, La Villa della Farnesina. Le pitture (Milan 2008)

Moormann 1995: E. M. Moormann (ed.), Mani di pittori e botteghe pittoriche nel mondo romano: tavola rotonda in onore di W. J. Th. Peters in occasione del suo 75.mo compleanno, MededRom 54, 1995, 61-298

Moormann 2007: E. M. Moormann, The Temple of Isis at Pompeii, in: L. Bricault - M. J. Versluys - G. P. Meyboom (eds.), Nile into Tiber. Egypt in the Roman World, Proceedings of the $3^{\text {rd }}$ International Conference of Isis Studies, Faculty of Archaeology, Leiden University, May 11-14, 2005 (Leiden 2007) 137-153

Moormann 2011: E. M. Moormann, Divine Interiors. Mural Paintings in Greek and Roman Sanctuaries, Amsterdam Archaeological Studies 16 (Amsterdam 2011)

Moormann 2018: E. M. Moormann, Ministers of Isiac Cults in Roman Wall Painting, in: V. Gasparini - R. Veymiers (eds.), Individuals and Materials in the Graeco-Roman Cultus of Isis. Agents, Images and Practices, Proceedings of the $6^{\text {th }}$ International Conference of Isis Studies, Erfurt, May 6-8, 2013 - Liège, September 23-24, 2013 (Leiden 2018) 366-383

Moret 2012a: J. M. Moret, Le feste dei Nani, in: C. Bocherens (ed.), Nani in festa. Iconografia, religione e politica a Ostia durante il secondo triumvirato (Bari 2012) 49-108

Moret 2012b: J. M. Moret, I nani di Antonio, in: C. Bocherens (ed.), Nani in festa. Iconografia, religione e politica a Ostia durante il secondo triumvirato (Bari 2012) 137-162

PPM 1990-2003: I. Baldassarre (ed.), Pompei Pitture e Mosaici, I-X, Istituto della Enciclopedia Italiana (Rome 1990-2003)

Salvadori 2018: M. Salvadori, Repertorio e scelte figurative di una 'bottega' di pittori a Pompei: il caso del frigidario delle Terme del Sarno, in: M. Cavalieri - C. Boschetti (eds.), Multa per aequora: il polisemico significato della moderna ricerca archeologica: omaggio a Sara Santoro (Louvain 2018) 527-545

Sampaolo 1992: V. Sampaolo, La decorazione pittorica, in: Alla ricerca di Iside. Analisi, studi e restauri dell'Iseo pompeiano nel Museo di Napoli (Naples 1992) 23-39

Sampaolo 1994: V. Sampaolo, I decoratori del Tempio di Isid, PP 49, 1994, 57-82

Sampaolo 1995: V. Sampaolo, I decoratori del Tempio di Iside a Pompei, in: E. M. Moormann (ed.), Mani di pittori e botteghe pittoriche nel mondo romano: tavola rotonda in onore di W. J. Th. Peters in occasione del suo 75.mo compleanno, MededRom 54, 1995, 200-213

Scagliarini et al. 2014: D. Scagliarini - A. Coralini - R. Helg, Davvero! La Pompei di fine '800 nella pittura di Luigi Bazzani, catalogo della mostra Bologna 26 marzo - 26 maggio 2013, Napoli 4 luglio 2013 - 6 gennaio 2014 (Bologna 2013)

Schefold 1975: K. Schefold, Die Trojasage in Pompeji, in: E. Berger - H. C. Ackermann (eds.), Wort und Bild. Studien zur Gegenwart der Antike (Basel 1975) 129-134 
Spinazzola 1953: V. Spinazzola, Pompei alla luce degli scavi nuovi di Via dell’Abbondanza (anni 1910-1923) (Rome 1953)

Tybout 2003: R. Tybout, Dwarfs in Discourse: The Function of Nilotic Scenes and other Roman Aegyptiaca, JRA 16, 2003, 505-515

Versluys 2002: M. J. Versluys, Aegyptiaca Romana. Nilotic Scenes and the Roman Views of Egypt, Religions in the Graeco-Roman World 144 (Leiden 2002)

Von Steinbüchel 1833: A. von Steinbüchel, Grosser antiquarischer Atlas, oder Abbildung der vorzüglichsten Denkmähler der alten Welt zu einer wissenschaftlichen Begründung der Alterthumskunde, nach den Vorträgen im K. K. Münz- und Antiken-Cabinett zu Wien (Vienna 1833) 
